Article

\title{
Is the Sharing Economy Green? Evidence from Cross-Country Data
}

\author{
Wei Yin ${ }^{1, *(\mathbb{D})}$, Berna Kirkulak-Uludag ${ }^{2}$ and Ziling Chen ${ }^{1}$ \\ 1 School of Economics and Management, Southeast University, Nanjing 210096, China; Zlchen97@163.com \\ 2 Faculty of Business, Dokuz Eylul University, Izmir 35390, Turkey; berna.kirkulak@deu.edu.tr \\ * Correspondence: yinwei_seu@126.com or yinwei_seu@seu.edu.cn
}

check for updates

Citation: Yin, W.; Kirkulak-Uludag, B.; Chen, Z. Is the Sharing Economy Green? Evidence from Cross-Country Data. Sustainability 2021, 13, 12023. https://doi.org/10.3390/su132112023

Academic Editor: Idiano D'Adamo

Received: 21 September 2021

Accepted: 28 October 2021

Published: 30 October 2021

Publisher's Note: MDPI stays neutral with regard to jurisdictional claims in published maps and institutional affiliations.

Copyright: (c) 2021 by the authors. Licensee MDPI, Basel, Switzerland. This article is an open access article distributed under the terms and conditions of the Creative Commons Attribution (CC BY) license (https:/ / creativecommons.org/licenses/by/ $4.0 /)$.

\begin{abstract}
Using cross-sectional data from 165 countries, this study takes a fresh look at whether or not the sharing economy is a green solution for countries. This study relies on the Timbro sharing economy index and uses both carbon emission and environmental performance index as proxies for the greenhouse gas effect and overall environment, respectively. Due to limited sample size and non-normal distribution of the sample, this paper applies the Bayesian regression model, which is based on posterior distribution. The findings suggest the following: (1) a high sharing economy level has a negative relationship to carbon emissions but a positive relationship to overall environmental performance; (2) the joint variables show that a high sharing economy level together with high broadband access, urbanization, and high education level reduces carbon emissions; and (3) for manufacturing countries, a high sharing economy level together with high urbanization is associated with comparatively low carbon emissions and high environmental performance. In general, these findings allow us to conclude in favor of the contribution made by a high sharing economy level to sustainability.
\end{abstract}

Keywords: sharing economy; carbon emission; overall environment; cross-country data; Bayesian analysis

\section{Introduction}

The sharing economy is one of the most important stylized facts of the new business models of our century. The concept of the sharing economy, in which assets and services are shared among individuals, has become very popular since it was introduced as an economic system. The sharing economy is defined as peer-to-peer-based activity of obtaining, giving, or sharing access to goods and services, coordinated through community-based online services [1]. Many synonymous names are used for the term 'sharing economy', such as gig economy, platform economy, access economy, and collaborative consumption [2]. Put simply, a sharing economy is used as an umbrella term for many apps, services, and products.

The main drivers of the growth of the sharing economy are population growth, urbanization, scarce resources, and the advent of technology. Many people have started to become aware of new ways to leverage the unused capacity of the things that they own or the services that they can provide. Consequently, there has been as move toward the sharing economy and it is now getting easier for platforms to connect people, foster sharing, and grow using smartphones, apps, and advanced online platforms. With the advent of technology, the sharing economy has changed the form of economic actives across many industries. The common practices of short-term rental platforms and car sharing have raised the public's awareness of the concept of the sharing economy [3]. Indeed, examples of the sharing economy are not limited to car or room rentals. A wide range of services are now provided by the sharing economy, including tourism, transportation, labor, delivery, short-term loans, retail, and consumer goods.

The sharing economy is not only attractive for financial reasons, but also because it creates social ties while leading to more sustainable practices. The sharing economy 
provides a sustainable perspective by aggregating the environmental, social, and economic aspects, and it addresses resource utilization through the temporary access rights to ownership of products or services [4,5]. At this point, the sharing economy positions itself as an environmentally friendly economy. With the efficient use of resources, sharing practices may reduce the adverse effects of human activities on the environment because the use of existing goods reduces the demand for new goods and hence leads to lower levels of waste. However, it is difficult to quantify how environmentally friendly the sharing economy is. In many industries, from short-term rental platforms to crowdfunding, it does not seem to be feasible to gauge how much energy, water, and greenhouse gas emissions people save by sharing. Perhaps only the transportation industry quantifies the potential reduction of energy consumption and emissions due to the fall in car purchases. The existing literature also supports the idea that car, bike, and motorbike sharing practices can help to promote the green environment [6-8].

Despite intense scholarly interest in the sharing economy, the nexus between the sharing economy and environmental degradation has not yet undergone a comprehensive review. The existing literature has examined the impact of the sharing economy on the environment, either for specific industries ([9] for bike sharing; [10] for car sharing) or for specific regions ([11] for Switzerland; [12] for the United States; [13] for China). Although a micro-level analysis of the sharing economy is interesting, it lacks the ability to make a comparison across countries. To date, there has been no study on the relationship between the sharing economy and environmental degradation using cross-country data. The current study attempts to fill this gap, which will have many implications for policy makers, practitioners, and academicians.

The aim of this study is to examine the relationship between the sharing economy level and environmental degradation. This study uses cross-country data from 165 countries, and it applies a Bayesian regression model. The level of the sharing economy is defined with the Timbro Sharing Economy Index (TSEI), which is the first global index of the sharing economy and has been available since 2018. TSEI provides a new definition of sharing economy that incorporates the use of excess capacity (e.g., labor, spare rooms, unused cars, etc.), large decentralized digital networks, and trust between strangers facilitated by infrastructure. These factors are used to create an economy that is characterized by micro-transactions, ad hoc matchmaking, and decentralized supply [14]. For environmental degradation, $\mathrm{CO}_{2}$ emissions per person $\left(\mathrm{CO}_{2} p c\right)$ and the Environment Performance Index $(E P I)$ are used. In previous studies, carbon dioxide has been widely used to measure the quality of the environment (e.g., $[15,16])$. Meanwhile, the EPI is a ranking system that indicates a country's efforts toward a sustainable future and is calculated by using 32 environmental performance indicators across 11 issue categories, as follows: air quality, health impacts, water and sanitation, water resources, agriculture, forests, fisheries, biodiversity and habitat, climate, and energy.

The development of the sharing economy has significantly changed production and consumption patterns all over the world. This leads us to ask whether the sharing economy practices have a significant impact on $\mathrm{CO}_{2}$ emissions and the overall environment. It is well-known that there has been no consensus regarding environment and sustainability issues internationally. However, the consequences of environmental degradation affect the entire globe, and this pushes us to be aware of how the sharing economy affects the environment from a global perspective. Using sharing economy index and environmental performance indicators in 165 countries, this paper empirically examines the impact of the sharing economy on countries' $\mathrm{CO}_{2}$ emissions and overall environment. Furthermore, this study is also interested in analyzing the joint effects of the sharing economy level and countries' different characteristics (e.g., income level, education, urbanization, etc.) to give a broader view of whether or not the sharing economy level is green.

The key findings of this paper are as follows. First, a high sharing economy level is associated with low $\mathrm{CO}_{2}$ emissions and high environment quality. This finding reflects that sharing economy practices can help to decrease carbon emissions and improve the 
overall environmental performance. Second, the development of information and Internet technology infrastructure has extended the positive impact of the sharing economy level on environmental performance. In particular, the use of the Internet helps people to access sharing economy platforms and broadband access enhances the capability of the sharing economy to reduce air pollution and improve environment quality. Third, there is a positive and significant relationship between carbon emissions and the joint variable of the sharing economy index, together with urbanization and education. This finding implies that urbanization improves the efficiency of sharing economy practices with a scale effect, and education raises awareness and concern for the environment. Moreover, one of the most striking findings of this paper is that major manufacturing countries that also have high sharing economy practices and high urbanization have comparatively low carbon emissions and high environment quality. The rest of this paper proceeds as follows. Section 2 reviews the literature. Section 3 describes the methodology and data. Section 4 discusses the empirical findings. Finally, Section 5 draws a conclusion and provides policy implications.

\section{Literature Review}

In attempts to contribute to the sharing economy literature, a considerable number of scholars have advanced our understanding of sharing economy platforms. There are large number of sharing economy platforms that provide a wide range of services, from job platforms to crowd funding platforms. The common feature of these platforms is the accessibility of products and services, rather than buying them. These platforms have revolutionized many conventional industries through decreasing transaction costs and enabling sharing economy companies to grab a significant market share [17-19]. The sharing economy is pushed by platform leverage, peer-to-peer interaction, and underutilized resources [20], as well as reciprocity norms and the social value of sharing [21]. The incumbent big firms have also played a crucial role in popularizing the sharing economy [22].

An extensive body of literature has analyzed the impact of the sharing economy on consumption. With the help of the sharing economy, the traditional methods of consumption have evolved from localized activities to global sharing activities. The sharing economy has altered the consumption patterns of individuals, and it has extended the incumbent business model of producers and consumers [1,23-28]. In addition, the widespread adoption of mobile phones and the rise of social media platforms has enabled individuals to become involved in more digitally connected economic activities and has also developed direct communication between suppliers and consumers [29].

The concept of the sharing economy and its practices also link to the circular economy. Sharing products or putting multi-functional products on the market can increase resource use efficiency [30]. Taking advantage of sharing information along the value chain can enhance collaboration in the circular economy [31]. Except for industry, the circular economy contributes to the sustainability of cities, in which sharing platforms are driving factors [32]. Sharing data is helpful for manufacturing companies to implement circular strategies [33]. In addition, the sharing vision is important for the local government's contribution to the implementation of the circular economy [34]. Hjaltadóttir and Hild [35] point out that sharing and circularity are both crucial in setting new economic models for the sustainability of the building industry in Europe. The sharing economy has had a considerable impact on the overall environment of many countries through the production side.

Education and income level are closely linked to the preference of sharing economy platform users. Many consumers are motivated by satisfaction, such as saving money or convenience. Sharing economy platforms provide additional choices, particularly to wealthy, educated citizens on the consumer side. In the eyes of many educated people, sharing platforms can act as a way of using a collaborative mindset, while trying to make life easier for users and for others. The findings of Andreotti et al. [36] reveal that the young generation with relatively higher income and higher education are more likely to participate in sharing economy activities. For instance, college graduates are found to 
be more likely to use car-sharing or home-sharing platforms. Meanwhile, lower income individuals can enjoy the increased availability of shared services and earn money by providing goods on sharing platforms to generate additional income. A minimum wealth level is necessary to render the platform users' own shareable property and maintain their active participation. Similarly, Eichhorn et al. [37] point out that education level and social capital are linked to digital inequality in the sharing economy.

Of additional interest from a scholarly point of view is the relationship between the sharing economy practices and environmental issues. While some of the existing literature supports the positive impact of sharing practices on the environment, some studies suggest that some sharing economy practices do not favor better environmental performance. In their paper, Bucher et al. [38] find that the sharing economy promotes more sustainable consumption. Ala-Mantila et al. [39], who find that sharing practices raise the awareness of environment quality, also support this view. Meanwhile, Paundra et al. [40] draw attention to the link between sustainability and sharing practices. They posit that, even if it is not intentional, consumers still use sustainable products and services through sharing platforms. Belk [41] argues that some features of the sharing economy are shared in common with hyper-capitalist marketplaces. To some extent, the sharing economy can bring remarkable benefits to society (e.g., environmental, socio-economical, communityrelated, and consumption-related benefits). For example, in the Chinese construction industry, sharing economy platforms have had a positive impact on the environment [42,43]. Cao and Shen [9] show that there is a negative relationship between the use of bike sharing and $\mathrm{CO}_{2}$ emissions in Beijing, where the riding distance of shared bikes is one of the most important factors behind the reduction of emissions. Moreover, Chen and Kockelman [10] show that sharing practices have reduced transportation energy use and greenhouse gas emissions by $51 \%$ in the United States. For Europe, Rydén and Morin [44] document that car sharing can lead an average decrease of $3000 \mathrm{~km}$ per year, and a $40-50 \%$ decrease in $\mathrm{CO}_{2}$ and $28 \%$ and $45 \%$ reduction in car use in Brussels and Bremen, respectively. Doka and Ziegler [11] compared the environmental impact of privately owned cars and car sharing in Switzerland and concluded that the overall footprint of a shared car is $39 \%$ less than that of a privately owned car. In a relatively recent study, Nijland and Meerkerk [6] surveyed car sharing in the Netherlands and their results reveal that there is a $15-20 \%$ decrease in car kilometers and 240 to $390 \mathrm{~kg}$ reduction in $\mathrm{CO}_{2}$ per person.

In contrast, some studies argue that the sharing economy has stimulated additional consumption and that the quality of the environment is not really a main concern of sharing economy platform users [45-47]. A similar conclusion comes from Lai and Ho [48], who state that the sharing economy can hardly reduce unnecessary consumption by consumers who are not ready to voluntary accept an eco-friendly culture. Similarly, Hu et al. [49] argue that only the sharing economy system together with corporate social responsibility practices can effectively lead to a "green" result. Moreover, Tussyadiah and Pesonen [50] suggest that the boost in the accommodation and transportation industries is due to the affordability of the sharing economy. However, the amount of travel has increased significantly, which places more pressure on the environment. In their study, Czepkiewcisz et al. [51] found that, although Airbnb has reduced accommodation costs, the carbon footprints of travelers has increased because of additional energy consumption and goods. In another study, Fishman et al. [52] cast some doubts on the sharing economy's environmental benefits. The authors of this paper argue that bike sharing actually increases motor vehicle usage, which can be observed from the reckless use of dockless bike sharing in China.

To ensure the environmental benefits of the sharing economy, the existing literature points to the gap in regulating sharing economy-based industries. Stemler [53] argues that existing laws cannot effectively regulate the sharing economy. Consequently, there is a need to balance the protection of users, service providers, and also of the workers of the existing businesses. Furthermore, Ganapati and Reddick [54] and Baumber et al. [55] suggest that the government should play a significant role in regulating and monitoring the sharing business models. This view is also supported by Mi and Coffman [56], who 
state that the government should regulate sharing economy activities and place priority on using taxes from sharing activities to promote sustainability.

\section{Methodology and Data}

This study first applies OLS regression and it then uses Bayesian regression. Unlike the classic linear regression coefficient estimation, Bayesian analysis treats regression parameters as random variables based on providing entire posterior distribution. This makes the Bayesian analysis superior at dealing with a small sample $[57,58]$.

Denote $X$ as the independent variables. $X=\left(x_{1}, x_{2}, \ldots, x_{k}\right)^{\prime}$, where $\mathrm{k}$ stands for $k$ variables. $x_{i}(i \in(1,2, \ldots, k))$ is the $1^{*} n$ vector, where $n$ stands for $n$ countries. Denote $Y$ as the environment-dependent variable. The basic Bayesian regression model is written as follows:

$$
Y=\alpha+\beta X+\varepsilon
$$

In Equation (1), $\alpha$ and $\beta$ are unknown parameters, $\varepsilon \sim N\left(0, \sigma^{2}\right)$. $X$ and $Y$ are observed samples. According to Bayesian regression method, the joint posterior distribution of $\alpha, \beta$, and $\sigma^{2}$ is given as follows:

$$
\begin{gathered}
P\left(\alpha, \beta, \sigma^{2} \mid Y, X\right) \propto P\left(\alpha, \beta, \sigma^{2}\right) \prod_{m=1}^{n} p\left(y_{m} \mid \alpha, \beta, \sigma^{2}, x_{m}\right) \\
\propto P\left(\alpha, \beta, \sigma^{2}\right) \exp \sum_{m=1}^{n}\left[-\frac{1}{2 \sigma^{2}}\left(y_{m}-\alpha-\beta x_{m}\right)^{2}\right]
\end{gathered}
$$

where $x_{m}=\left(x_{1}^{m}, x_{2}^{m}, \cdots, x_{k}^{m}\right)$. Assume that $\alpha, \beta$, and $\sigma^{2}$ are independent of each other. The prior distributions of these parameters are given as $p(\alpha) \propto N\left(0,10^{4}\right), p(\beta) \propto N\left(0,10^{4}\right)$, and $p\left(\sigma^{2}\right) \propto$ Inverse Gamma $(0.01,0.01)$, respectively. According to conjugate distribution method, the conditional posterior distribution of $\alpha$ can be estimated as $N\left(\bar{\alpha}, S_{0}^{2}\right)$, where

$$
\bar{\alpha}=\frac{1}{n} \sum_{m=1}^{n}\left(y_{m}-\alpha-\beta x_{m}\right), S_{0}^{2}=\frac{\sigma^{2}}{n}
$$

Using the same method, we can get the conditional posterior distribution of $\beta$ is $N\left(\bar{\beta}, S_{1}^{2}\right)$, where

$$
\bar{\beta}=\left(X^{\prime} X\right)^{-1} X^{\prime}(Y-\alpha), S_{1}^{2}=\left(X^{\prime} X\right)^{-1} \sigma^{2}
$$

The conditional posterior distribution of $\sigma^{2}$ is still inverse gamma distribution, which can be written as:

$$
\sigma^{2} \sim \frac{1}{\Gamma} \sum_{m=1}^{n}\left(y_{m}-\alpha-\beta x_{m}\right)^{2}
$$

Following the previous studies [59,60], we use the Markov Chain Monte Carlo (MCMC) to explore the posterior distribution of parameters to solve the bias caused by the small sample and extreme values. We set two variables as a proxy for environmental degradation, which are $\mathrm{CO}_{2}$ emissions per person and the Environment Performance Index. The key independent variable is the TSEI. X stands for the control variables. The benchmark regression models are designed as follows:

$$
\begin{gathered}
\mathrm{LnCO}_{2} p c_{i}=\alpha_{0}+\alpha_{1} \mathrm{TSEI}_{i}+\mathrm{X} \gamma+\mu_{i} \\
E P I_{i}=\beta_{0}+\beta_{1} \mathrm{TSEI}_{i}+\mathrm{X} \delta+\varepsilon_{i}
\end{gathered}
$$

In Equations (6) and (7), two dependent variables are used to measure the environmental degradation, which are $\mathrm{CO}_{2}$ emissions per person $\left(\mathrm{CO}_{2} p c\right)$ and $E P I$, respectively. In previous studies, carbon dioxide has been widely used to measure the quality of the environment (e.g., [15,16]). The EPI data came from the Yale Center for Environmental Law and Policy, which is an index evaluation system that includes 32 performance indicators across 11 issue categories (e.g., air quality, wastewater, agriculture etc.), ranking 180 countries on environmental health and ecosystem vitality (further details can be accessed at epi.yale.edu/, accessed on 20 April 2020). The EPI has a distribution from 0 to 100, which 
indicates that the higher values indicate a higher quality environment. The key variable standing for sharing economy is the TSEI. Timbro is a famous and large free market think tank that was established in 1978 in Sweden. Given that the sharing economy index was released in 2018, the sampling period only covers the year 2018 for 165 countries. The TSEI index takes values ranging from 0 to 100, in which the higher value indicates a higher sharing economy level. This index was compiled using traffic volume data and scraped data. In particular, monthly data were collected for 286 services in 213 countries. For 23 of the 286 services, Timbro used automated web scraping techniques (further details can be found at timbro.se/ekonomi/timbro-sharing-economy-index/, accessed on 18 April 2020).

Following the previous studies, six control variables are included in Equations (6) and (7). The variable of GDPpc stands for real GDP per capita, which measures the macro effect on the environment (e.g., [16]). The Industrial variable measures the ratio of value added in secondary industry production over GDP, which reflects the impact of the industrial structure on environment (see $[61,62]$ ). Popdensity is the density of the population, which is found to be highly linked to $\mathrm{CO}_{2}$ emissions [62,63]. Education is found to be a factor related to the environment $[64,65]$. This paper uses the average years of schooling of a country to represent the average education level. Tradefreedom is the trade freedom index of each country, which is given by the US Heritage Foundation (further details can be found on www.heritage.org/, accessed on 20 April 2020). A higher trade freedom value indicates a higher trade freedom [66]. Urban refers to the proportion of people living in urban areas [67]. To overcome the potential endogeneity problem, the lagged values of GDPpc, Industrial, Popdensity, Education, and Tradefreedom were used (L stands for lagged terms). Equations (6) and (7) can be rewritten as follows.

$$
\begin{aligned}
& \text { LnCO }_{2} p c_{i}=\alpha_{0}+\alpha_{1} \text { TSEI }_{i}+\alpha_{2} \operatorname{L.Ln}(\text { GDPpc })_{i}+\alpha_{3} \text { L.Industrial }_{i}+\alpha_{4} \text { L.Popdensity }_{i} \\
& +\alpha_{5} \text { L.Education }_{i}+\alpha_{6} \text { L.Tradefreedom }_{i}+\alpha_{7} \text { L. Urban }_{i}+\mu_{i} \\
& E P I_{i}=\beta_{0}+\beta_{1} \text { TSEI }_{i}+\beta_{2} \text { L.Ln }(\text { GDPpc })_{i}+\beta_{3} \text { L.Industrial }_{i}+\beta_{4} \text { L.Popdensity }_{i} \\
& +\beta_{5} \text { L.Education }_{i}+\beta_{6} \text { L.Tradefreedom }_{i}+\alpha_{7} \text { L.Urban }_{i}+\varepsilon_{i}
\end{aligned}
$$

In further regressions, we set a dummy variable to distinguish different groups of countries. Top10broadband represents the top 10 countries by Internet use per person in 2018. Variable broadband, which is measured by broadband access use per person, was set as an instrument in the robustness check.

The data were extracted from several sources. The carbon dioxide emission data came from the Emissions Database for Global Atmospheric Research (EDGAR) and the EPI data were collected from Yale Center for Environmental Law and Policy. TSEI is published by Timbro. The trade freedom data for these countries came from the Heritage Foundation database (available at www.heritage.org/, accessed on 20 April 2020). The education data came from "Our World in Data" (ourworldindata.org/, accessed on 18 April 2020). Other data were collected from the World Bank database.

The sample is one of the main limitations of this study because it is not appropriate for time series analyses. TSEI data were only available for the year 2018. This led us to deal with cross-sectional data and use regression analyses. The definitions of the variables and summary statistics are given in Table 1.

The scatter graph in Figure 1 shows that, while the relationship between $\operatorname{LnCO} \mathrm{O}_{2} \mathrm{pc}$ and TSEI is weakly positive, the relationship between EPI and TSEI is strongly positive. Therefore, it seems that the environmental performance will be better when the sharing economy level is higher. However, the graph also suggests that, while the sharing index is high, the carbon emissions also appear to be high. Further evidence will be presented in the empirical part of this paper. 
Table 1. Variable definition and summary statistics.

\begin{tabular}{|c|c|c|c|c|c|c|c|}
\hline Variable & Definition & Unit & Mean & S.D. & Max & Min & Have \\
\hline $\mathrm{CO}_{2} p c$ & $\mathrm{CO}_{2}$ emissions per person & Kilo/person & 4758.848 & 5962.382 & $38,190.000$ & 30.000 & 165 \\
\hline EPI & $\begin{array}{c}\text { Environment } \\
\text { performance level }\end{array}$ & - & 56.182 & 12.942 & 87.420 & 27.430 & 165 \\
\hline TSEI & Sharing economy level & - & 5.178 & 9.800 & 58.200 & 0.000 & 165 \\
\hline GDPpc & Real GDP per capita & USD/person & $13,697.560$ & $19,535.760$ & $109,453.000$ & 214.140 & 165 \\
\hline Industrial & $\begin{array}{l}\text { Value added in secondary } \\
\text { industry/GDP }\end{array}$ & $\%$ & 26.817 & 11.998 & 77.541 & 2.311 & 165 \\
\hline Popdensity & Population density & $\begin{array}{l}\text { Thousand/ } \\
\text { sq.km }\end{array}$ & 0.202 & 0.658 & 7.916 & 0.002 & 165 \\
\hline Education & $\begin{array}{l}\text { Average years } \\
\text { of schooling }\end{array}$ & Year & 8.505 & 3.137 & 14.100 & 1.500 & 165 \\
\hline Tradefreedom & Trade freedom level & - & 75.721 & 10.686 & 90.000 & 40.000 & 165 \\
\hline Urban & $\begin{array}{l}\text { Urban population/ } \\
\text { total population }\end{array}$ & $\%$ & 58.676 & 22.268 & 100.000 & 12.706 & 165 \\
\hline Top10broadband ${ }^{a}$ & $\begin{array}{l}\text { Dummy variable, Top } 10 \\
\text { Broadband access use per } \\
\text { person countries in the } \\
\text { world }=1 \text {, otherwise }=0\end{array}$ & - & 0.061 & 0.239 & 1 & 0 & 165 \\
\hline Broadband & $\begin{array}{l}\text { Broadband access use } \\
\text { per person }\end{array}$ & - & 0.126 & 0.135 & 0.463 & $1 \times 10^{-5}$ & 165 \\
\hline
\end{tabular}

Note: a According to the World Bank's WDI database, the top 10 countries ranked by broadband access per person in 2018 were Switzerland, France, the Netherlands, South Korea, Malta, Norway, Germany, Sweden, the United Kingdom, and Belgium.
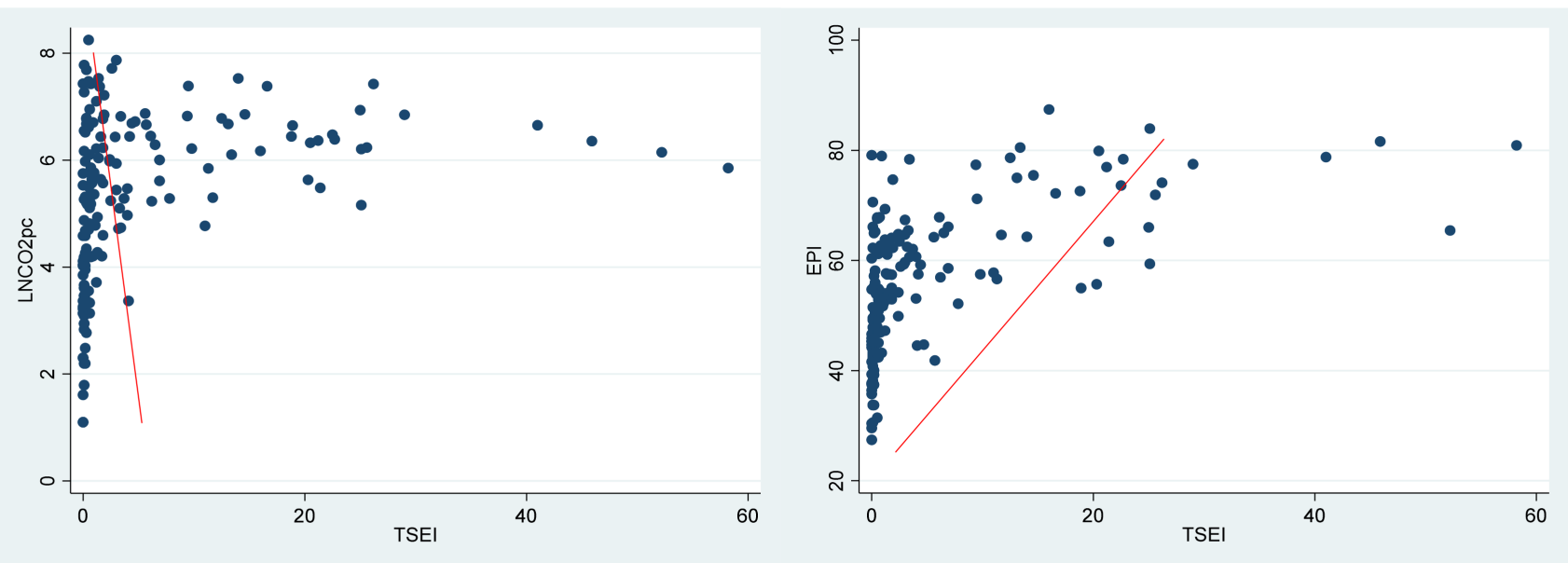

Figure 1. Scatter graph for the relationships of $L n \mathrm{CO}_{2} p c-T S E I$ and EPI-TSEI.

\section{The Empirical Findings}

\subsection{OLS Regression Results and Model Selection}

Tables 2 and 3 report the benchmark regression results using OLS linear regression model (We used an OLS bootstrap regression (500 times) method as a robustness check and our results remained the same. The results are available from the authors upon request). While TSEI is negatively correlated with $\mathrm{CO}_{2}$ emission, it is positively correlated with overall environmental performance (EPI). Regressions (1)-(6) in Tables 2 and 3 provide stable results for the independent variables. This paper further checks the existence of a heterogonous problem by using B-P test and White test. The results are given in Table 4. Both tests show no heteroscedasticity in the regressions. 
Table 2. The sharing economy level and carbon emissions using OLS.

\begin{tabular}{|c|c|c|c|c|c|c|}
\hline & $\begin{array}{c}\text { (1) } \\
\mathrm{LnCO}\end{array}$ & $\begin{array}{c}(2) \\
\mathrm{LnCO} \\
2 p c\end{array}$ & $\begin{array}{c}(3) \\
\mathrm{LnCO}\end{array}$ & $\begin{array}{c}(4) \\
\mathrm{LnCO}\end{array}$ & $\begin{array}{c}(5) \\
\mathrm{LnCO}\end{array}$ & $\begin{array}{c}\text { (6) } \\
\mathrm{LnCO} \mathrm{O}_{2} p c\end{array}$ \\
\hline TSEI & $\begin{array}{c}-0.028^{* * *} \\
(0.006)\end{array}$ & $\begin{array}{c}-0.018 * * * \\
(0.007)\end{array}$ & $\begin{array}{c}-0.018^{* * *} \\
(0.007)\end{array}$ & $\begin{array}{c}-0.017^{* * *} \\
(0.006)\end{array}$ & $\begin{array}{c}-0.017^{* * *} \\
(0.006)\end{array}$ & $\begin{array}{c}-0.017^{* * *} \\
(0.006)\end{array}$ \\
\hline LnGDPpc & $\begin{array}{c}1.030 * * * \\
(0.044)\end{array}$ & $\begin{array}{c}0.971 * * * \\
(0.045)\end{array}$ & $\begin{array}{c}0.977^{* * * *} \\
(0.045)\end{array}$ & $\begin{array}{c}0.753^{* * *} \\
(0.065)\end{array}$ & $\begin{array}{c}0.758^{* * *} \\
(0.066)\end{array}$ & $\begin{array}{c}0.654^{* * *} \\
(0.078)\end{array}$ \\
\hline Industrial & & $\begin{array}{c}0.018^{* * *} \\
(0.005)\end{array}$ & $\begin{array}{c}0.018^{* * *} \\
(0.005)\end{array}$ & $\begin{array}{c}0.021^{* * *} \\
(0.005)\end{array}$ & $\begin{array}{c}0.021^{* * *} \\
(0.005)\end{array}$ & $\begin{array}{c}0.020 * * * \\
(0.005)\end{array}$ \\
\hline Popdensity & & & $\begin{array}{l}-0.061 \\
(0.081)\end{array}$ & $\begin{array}{c}-0.027 \\
(0.076)\end{array}$ & $\begin{array}{c}-0.024 \\
(0.077)\end{array}$ & $\begin{array}{c}-0.036 \\
(0.076)\end{array}$ \\
\hline Education & & & & $\begin{array}{c}0.123^{* * * *} \\
(0.027)\end{array}$ & $\begin{array}{c}0.129 * * * \\
(0.028)\end{array}$ & $\begin{array}{c}0.130 * * * \\
(0.028)\end{array}$ \\
\hline Tradefreedom & & & & & $\begin{array}{c}-0.004 \\
(0.006)\end{array}$ & $\begin{array}{l}-0.002 \\
(0.006)\end{array}$ \\
\hline Urban & & & & & & $\begin{array}{c}0.008^{* *} \\
(0.003)\end{array}$ \\
\hline Constant & $\begin{array}{c}-8.005^{* * *} \\
(0.364)\end{array}$ & $\begin{array}{c}-8.044^{* * *} \\
(0.350)\end{array}$ & $\begin{array}{c}-8.0711^{* * *} \\
(0.352)\end{array}$ & $\begin{array}{c}-7.284^{* * *} \\
(0.374)\end{array}$ & $\begin{array}{c}-7.080 \text { *** } \\
(0.486)\end{array}$ & $\begin{array}{c}-6.779 \text { *** } \\
(0.496)\end{array}$ \\
\hline Observations & 165 & 165 & 165 & 165 & 165 & 165 \\
\hline R-squared & 0.797 & 0.814 & 0.815 & 0.836 & 0.837 & 0.842 \\
\hline
\end{tabular}

Note: ${ }^{* *}$ significant at $5 \%$; *** significant at $1 \%$; values in parentheses are standard deviations.

Table 3. The sharing economy and overall environmental performance using OLS.

\begin{tabular}{|c|c|c|c|c|c|c|}
\hline & $\begin{array}{c}(1) \\
E P I\end{array}$ & $\begin{array}{c}(2) \\
E P I\end{array}$ & $\begin{array}{c}(3) \\
E P I\end{array}$ & $\begin{array}{c}(4) \\
E P I\end{array}$ & $\begin{array}{c}(5) \\
E P I\end{array}$ & $\begin{array}{c}(6) \\
E P I\end{array}$ \\
\hline TSEI & $\begin{array}{c}0.213^{* * *} \\
(0.060)\end{array}$ & $\begin{array}{l}0.120 * \\
(0.063)\end{array}$ & $\begin{array}{l}0.111 \text { * } \\
(0.062)\end{array}$ & $\begin{array}{l}0.114 * \\
(0.060)\end{array}$ & $\begin{array}{l}0.105 * \\
(0.059)\end{array}$ & $\begin{array}{l}0.107 \text { * } \\
(0.059)\end{array}$ \\
\hline LnGDPpc & $\begin{array}{c}6.942 * * * \\
(0.407)\end{array}$ & $\begin{array}{c}7.487^{* * *} \\
(0.416)\end{array}$ & $\begin{array}{c}7.659 * * * \\
(0.416)\end{array}$ & $\begin{array}{c}6.280^{* * *} \\
(0.617)\end{array}$ & $\begin{array}{c}6.102^{* * *} \\
(0.610)\end{array}$ & $\begin{array}{c}5.392 * * * \\
(0.731)\end{array}$ \\
\hline Industrial & & $\begin{array}{c}-0.170^{* * *} \\
(0.044)\end{array}$ & $\begin{array}{c}-0.181 * * * \\
(0.044)\end{array}$ & $\begin{array}{c}-0.163 * * * \\
(0.043)\end{array}$ & $\begin{array}{c}-0.157^{* * *} \\
(0.043)\end{array}$ & $\begin{array}{c}-0.166^{* * * *} \\
(0.043)\end{array}$ \\
\hline Popdensity & & & $\begin{array}{c}-1.789 * * \\
(0.739)\end{array}$ & $\begin{array}{c}-1.579 * * \\
(0.725)\end{array}$ & $\begin{array}{c}-1.679 * * \\
(0.714)\end{array}$ & $\begin{array}{c}-1.758^{* *} \\
(0.710)\end{array}$ \\
\hline Education & & & & $\begin{array}{c}0.759^{* * *} \\
(0.255)\end{array}$ & $\begin{array}{c}0.548 \text { ** } \\
(0.264)\end{array}$ & $\begin{array}{c}0.557^{* *} \\
(0.262)\end{array}$ \\
\hline Tradefreedom & & & & & $\begin{array}{c}0.141^{* * *} \\
(0.055)\end{array}$ & $\begin{array}{c}0.153^{* * *} \\
(0.055)\end{array}$ \\
\hline Urban & & & & & & $\begin{array}{l}0.056^{*} \\
(0.032)\end{array}$ \\
\hline Constant & $\begin{array}{l}-4.572 \\
(3.389) \\
\end{array}$ & $\begin{array}{l}-4.209 \\
(3.256)\end{array}$ & $\begin{array}{l}-4.980 \\
(3.223)\end{array}$ & $\begin{array}{l}-0.132 \\
(3.545)\end{array}$ & $\begin{array}{c}-7.561 * \\
(4.521)\end{array}$ & $\begin{array}{c}-5.502 \\
(4.646)\end{array}$ \\
\hline Observations & 165 & 165 & 165 & 165 & 165 & 165 \\
\hline R-squared & 0.754 & 0.774 & 0.782 & 0.794 & 0.802 & 0.806 \\
\hline
\end{tabular}

Note: * significant at $10 \% ;{ }^{* *}$ significant at $5 \%$; ${ }^{* * *}$ significant at $1 \%$. Values in parentheses are standard deviations.

Table 4. Results of the heteroscedasticity test of the OLS linear regression model.

\begin{tabular}{ccc}
\hline & LnCO & EPI \\
\hline Breusch-Pagan/Cook-Weisberg test & $1.95(0.1630)$ & $1.91(0.1675)$ \\
White test & $45.56(0.1091)$ & $30.04(0.7064)$
\end{tabular}

Note: The values in the table are chi-squared statistics for Breusch-Pagan/Cook-Weisberg test and White test. Values in parentheses are probabilities corresponding to the statistics.

We then have a normal distribution check on the residuals of the two regressions. The results are presented in Figure 2, suggesting that the residual distributions are not normally distributed. To get more accurate results, this paper applies a Bayesian regression model, which is based on posterior distribution, to solve the distribution problem. 


\section{Residuals for LNCO2pc:TSEI}
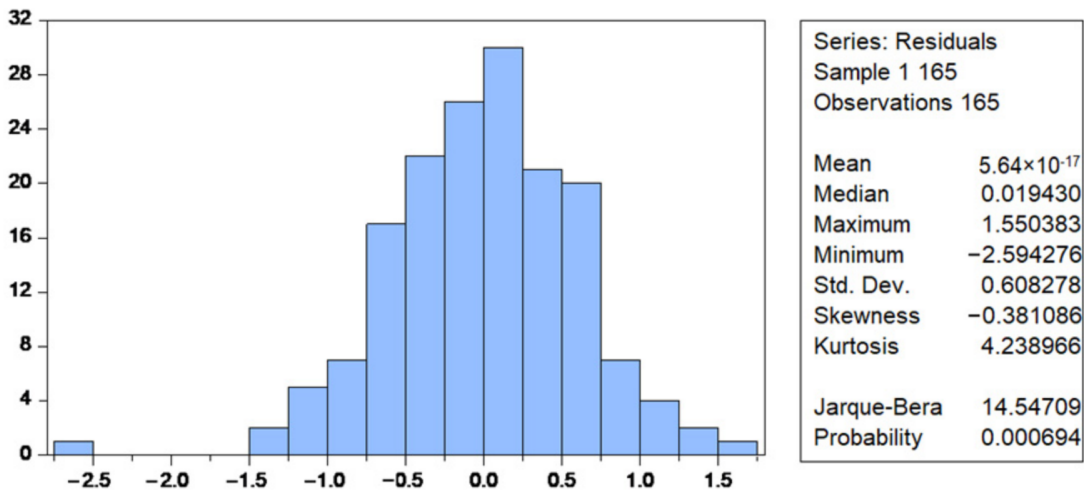

Residuals for EPI:TSEI

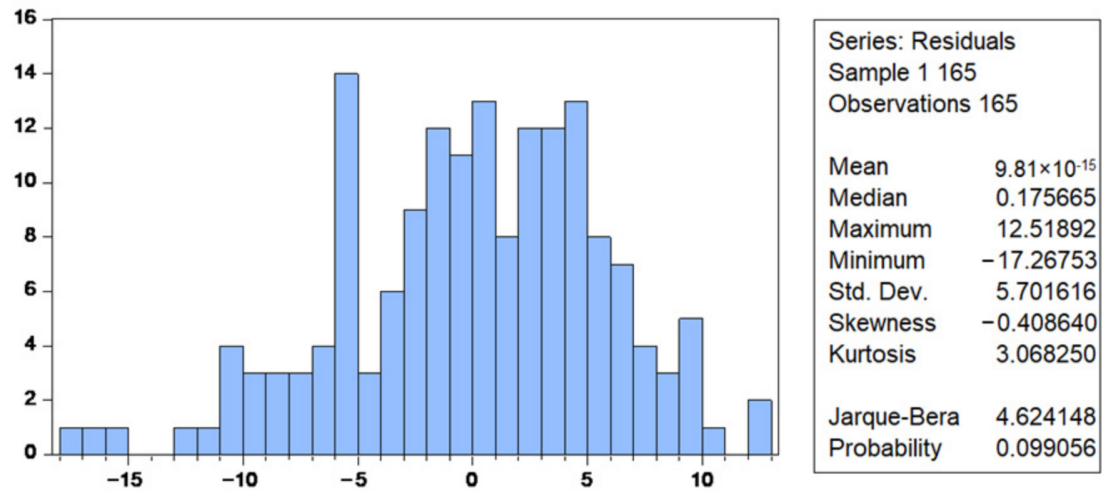

Figure 2. Normal distribution test of OLS linear regression model.

\subsection{Benchmark Regression Results with a Bayesian Model}

This paper used Gibb's sampling with 12,500 MCMC iterations on the sample, while excluding the first 2500 samples to avoid the biased influence on the initial value (The unreported Pearson correlation test indicates multicollinearity between GDPpc and Education (with a correlation value of 0.807). However, the Bayesian regression is free of the multicollinearity problem. The results are available upon request.) The benchmark regression results of the Bayesian model are given in Table 5.

Table 5. The sharing economy level, carbon emissions, and overall environmental performance.

\begin{tabular}{|c|c|c|c|c|c|c|c|c|}
\hline & \multicolumn{4}{|c|}{$\mathrm{LnCO}_{2} p c$} & \multicolumn{4}{|c|}{$E P I$} \\
\hline & Mean & S.D. & MCSE & 95\% Cred Interval & Mean & S.D. & MCSE & $95 \%$ Cred Interval \\
\hline TSEI & -0.017 & 0.006 & 0.000 & {$[-0.029,-0.005]$} & 0.107 & 0.059 & 0.001 & {$[0.012,0.223]$} \\
\hline LnGDPpc & 0.655 & 0.079 & 0.001 & {$[0.499,0.807]$} & 5.401 & 0.734 & 0.007 & {$[3.969,6.846]$} \\
\hline Industrial & 0.020 & 0.005 & 0.000 & {$[0.011,0.029]$} & -0.165 & 0.043 & 0.000 & {$[-0.249,-0.082]$} \\
\hline Popdensity & -0.036 & 0.077 & 0.001 & {$[-0.185,0.116]$} & -1.749 & 0.719 & 0.007 & {$[-3.181,-0.344]$} \\
\hline Education & 0.130 & 0.028 & 0.000 & {$[0.075,0.185]$} & 0.556 & 0.259 & 0.003 & {$[0.037,1.060]$} \\
\hline Tradefreedom & -0.002 & 0.006 & 0.000 & {$[-0.014,0.009]$} & 0.153 & 0.054 & 0.001 & {$[0.047,0.259]$} \\
\hline Urban & 0.008 & 0.003 & 0.000 & {$[0.001,0.015]$} & 0.056 & 0.032 & 0.000 & {$[-0.007,0.121]$} \\
\hline $\mathrm{C}$ & -6.782 & 0.501 & 0.005 & {$[-7.764,-5.803]$} & -5.595 & 4.640 & 0.046 & {$[-14.423,3.699]$} \\
\hline
\end{tabular}

Table 5 reports the Bayesian results for the value of mean, posterior standard deviation (S.D.), MCSE, and 95\% credible interval. The results indicate low Monte Carlo standard errors (MCSEs) in both models, which suggests that the parameter estimated by the MCMC simulation is stable. Furthermore, given that MCSE is a function of the number of iterations 
in the simulation, using 12,500 iterations is an appropriate choice. In Table 5, TSEI shows a negative relationship with $L n \mathrm{CO}_{2} p c$. The mean of TSEI is -0.018 . The estimation range of the posterior mean for TSEI is $[-0.030,-0.006]$. This suggests that high sharing economy index reduces carbon emissions. For environmental performance, the sharing economy index still has a positive correlation with a mean of 0.102 , and the $95 \%$ credit interval falls between 0.014 and 0.221 . This result indicates that high sharing economy level can help to improve the general environment quality.

The findings in Table 5 show that $L n G D P p c$ has a positive impact on the dependent variables. Developed countries with higher GDP per capita usually have a heavier burden to decrease $\mathrm{CO}_{2}$ emissions than developing countries. However, the overall environment of developed countries is, on average, better than that of developing countries. Table 5 presents that, while the industrial variable has a positive relationship with $L n \mathrm{CO}_{2} p c$, it has a negative relationship with EPI. This result posits that a higher proportion of the industry sector is associated with higher $\mathrm{CO}_{2}$ emissions and lower environmental performance. The reason for this is that the industrial sector is dominated by manufacturing of finished products, while high carbon emissions and low environmental performance indicate environmental degradation. Similar to previous studies [67], a high education level has a positive effect on carbon emissions. Therefore, education has a positive relationship with EPI. Furthermore, Urban also has positive impact on carbon emission proxy variables. Consistent with Madlener and Sunak [68], urbanization will aggravate air pollution, due to high energy consumption and low efficiency.

Regarding the Popdensity, the results show that higher population density is linked to lower carbon emissions. In fact, the dense clustering of people enables economies of scale through providing goods and services more cost effectively. Infrastructures in urban areas enable people to benefit from shared services and thus induce lower environmental degradation. Consequently, countries with large population densities may have lower carbon emissions in comparison with suburban areas. This can be attributed to public transport services and walking accessibility. Large cities with a high population density tend to have more comprehensive transit systems and lower reliance on personal vehicles. In particular, vehicular population decreases because people live closer together in densely populated areas [69-71]. It is also important to note that, overall, a dense population threatens the environment through the consumption of resources. Finally, the findings on trade freedom suggest that free trade decreases the carbon emission and increases environmental performance. In line with the argument of Grossman and Krueger [66], international trade brings new technology, which helps the home country to improve production efficiency and decrease the energy consumption.

Figure 3 illustrates the efficiency check of MCMC simulation of TSEI to $\operatorname{LnCO} \mathrm{O}_{2} p c$. The vast majority of the lines drawn in the trace graph are vertical and dense. This indicates that the MCMC chain does not have convergence problems. The autocorrelation problem does not exist. The histogram plot shows a normal distribution of marginal posterior, which is consistent with our assumption for prior distribution. In the density graph, the three density curves are close to each other. This suggests that the MCMC chain has converged and mixed well. Figure 4 reports similar results of effective convergence for the MCMC simulation of TSEI to EPI.

\subsection{Joint-Effect Analysis with a Bayesian Model}

Given that the sharing economy is highly dependent on the information and Internet technology [72], it is important to measure the impact of this joint variable on the environment. Table 6 documents the results for the variable of TSEI*Top10broadband (Because the broadband access level has significant impact on the TSEI (see the report "Timbro sharing economy index", pages 34 and 35), we set a dummy variable of Top10broadband access countries instead of taking it as a continuous variable at the expense of the selection bias problem), which represents the joint effect of sharing economy level and Internet usage per person. The results show that TSEI*Top10broadband variable is negatively associated 
with $\mathrm{LnCO}_{2} p c$, with a 95\% credible interval estimation range of [-0.037, -0.003$]$. This implies that broadband access supports sharing economy activities, and thus helps to decrease carbon emissions. The next thing to consider is the impact of this joint variable

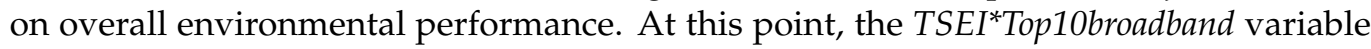
has a positive impact on EPI (with a mean of 0.179 ) with a $95 \%$ credible interval estimation range of $[0.016,0.347]$. This result supports the notion again that broadband access enhances the sharing economy activities, and thus helps to improve the overall environmental performance.

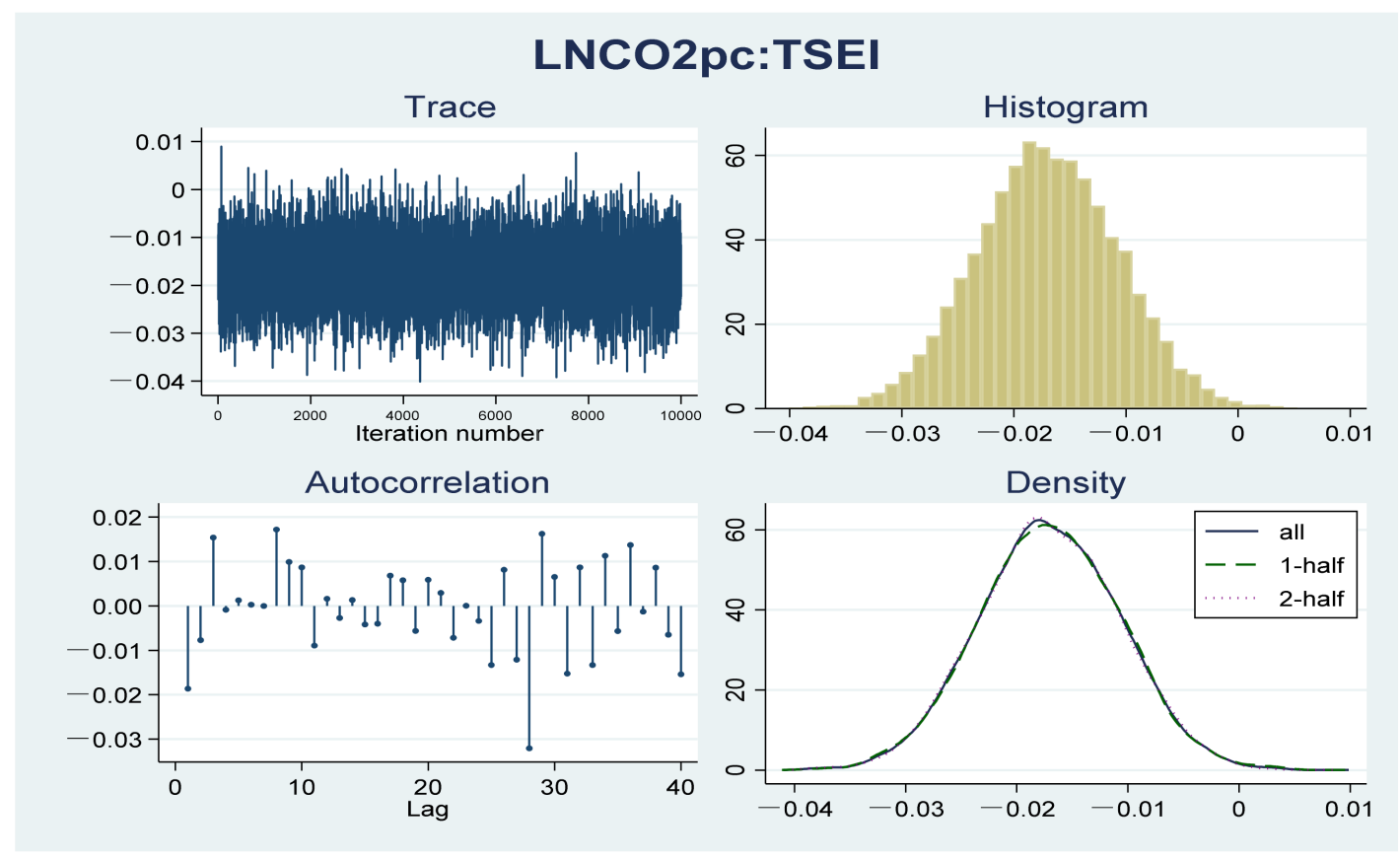

Figure 3. An efficiency check of the MCMC simulation of TSEI to $\mathrm{LnCO}_{2} p c$.

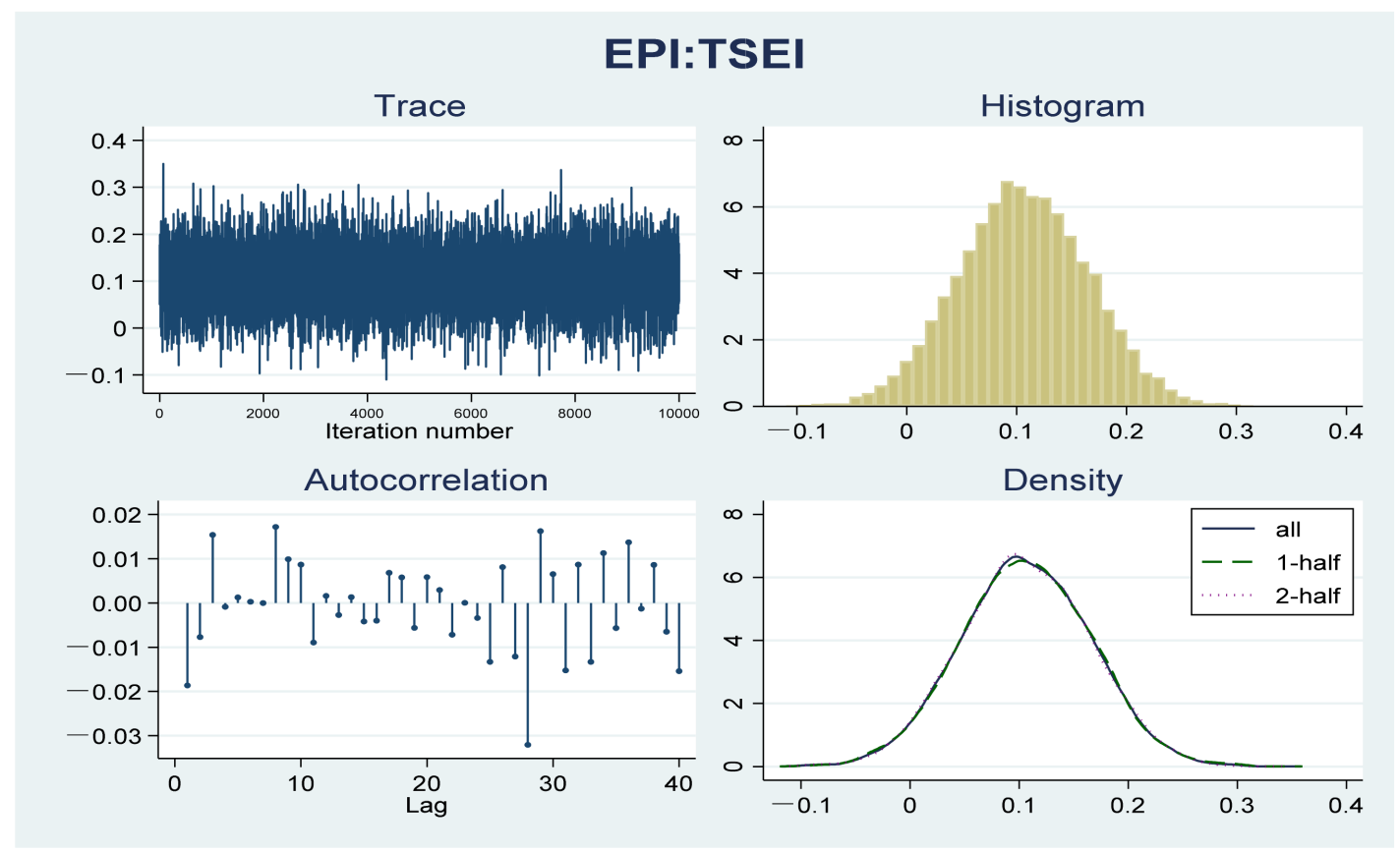

Figure 4. An efficiency check of the MCMC simulation of TSEI to EPI. 
Table 6. Joint effect of TSEI and Internet popularity on carbon emissions and overall environmental performance.

\begin{tabular}{ccccccccc}
\hline & \multicolumn{3}{c}{ LnCO $_{2} p c$} & & \multicolumn{2}{c}{ EPI } \\
\cline { 2 - 9 } & Mean & S.D. & MCSE & 95\% Cred Interval & Mean & S.D. & MCSE & 95\% Cred Interval \\
\hline TSEI & -0.006 & 0.007 & 0.000 & {$[-0.020,0.008]$} & 0.030 & 0.070 & 0.001 & {$[-0.106,0.165]$} \\
TSEI $\times$ Top10 & -0.024 & 0.009 & 0.000 & {$[-0.042,-0.007]$} & 0.170 & 0.085 & 0.001 & {$[0.005,0.338]$} \\
broadband & 0.648 & 0.077 & 0.001 & {$[0.498,0.800]$} & 5.428 & 0.721 & 0.007 & {$[4.035,6.845]$} \\
LnGDPpc & 0.020 & 0.004 & 0.000 & {$[0.011,0.029]$} & -0.168 & 0.043 & 0.000 & {$[-0.250,-0.084]$} \\
Industrial & -0.023 & 0.075 & 0.001 & {$[-0.171,0.126]$} & -1.837 & 0.717 & 0.007 & {$[-3.237,-0.439]$} \\
Popdensity & 0.127 & 0.028 & 0.000 & {$[0.072,0.181]$} & 0.586 & 0.261 & 0.003 & {$[0.074,1.103]$} \\
Education & -0.002 & 0.006 & 0.000 & {$[-0.013,0.009]$} & 0.151 & 0.055 & 0.001 & {$[0.045,0.258]$} \\
Tradefreedom & 0.009 & 0.003 & 0.000 & {$[0.002,0.016]$} & 0.050 & 0.032 & 0.000 & {$[-0.013,0.114]$} \\
Urban & -6.796 & 0.492 & 0.005 & {$[-7.770,-5.828]$} & -5.386 & 4.593 & 0.047 & {$[-14.362,3.637]$} \\
C & & & & & & & &
\end{tabular}

Table 7 shows the joint effect of variable TSEI*Urban on carbon emissions and overall environmental performance. TSEI*Urban has a negative impact on $\mathrm{LnCO}_{2} \mathrm{pc}$ with a 95\% credible interval estimation range of $[-0.001,-0.000]$, which supports the notion that urbanization tends to enhance the negative effect of the sharing economy level on carbon emissions. Sharing economy activities can reduce transaction costs and create more social values [73]. The Urban variable has a positive impact on $\mathrm{LnCO}_{2} p c$, which suggests that the development of the sharing economy is a possible solution to limit carbon emissions. The EPI result also shows that TSEI*Urban has a positive mean with a $95 \%$ credible interval estimation ranging from -0.002 to 0.010 . An increase in sharing economy activities contributes to the sustainability of cities.

Table 7. Joint effect of TSEI and urbanization on carbon emission and overall environmental performance.

\begin{tabular}{ccccccccc}
\hline & \multicolumn{3}{c}{ LnCO $_{2} p c$} & & \multicolumn{2}{c}{ EPI } \\
\cline { 2 - 8 } & Mean & S.D. & MCSE & 95\% Cred Interval & Mean & S.D. & MCSE & 95\% Cred Interval \\
\hline TSEI & 0.050 & 0.025 & 0.000 & {$[0.002,0.097]$} & -0.209 & 0.238 & 0.002 & {$[-0.676,0.259]$} \\
TSEI $\times$ Urban & -0.001 & 0.000 & 0.000 & {$[-0.001,-0.000]$} & 0.004 & 0.003 & 0.000 & {$[-0.002,0.010]$} \\
LnGDPpc & 0.638 & 0.077 & 0.001 & {$[0.484,0.792]$} & 5.478 & 0.735 & 0.007 & {$[4.036,6.900]$} \\
Industrial & 0.019 & 0.004 & 0.000 & {$[0.010,0.028]$} & -0.162 & 0.043 & 0.000 & {$[-0.246,-0.079]$} \\
Popdensity & -0.017 & 0.075 & 0.001 & {$[-0.165,0.129]$} & -1.832 & 0.718 & 0.007 & {$[-3.241,-0.437]$} \\
Education & 0.124 & 0.027 & 0.000 & {$[0.070,0.178]$} & 0.583 & 0.266 & 0.003 & {$[0.062,1.111]$} \\
Tradefreedom & -0.002 & 0.006 & 0.000 & {$[-0.013,0.010]$} & 0.152 & 0.056 & 0.001 & {$[0.042,0.262]$} \\
Urban & 0.011 & 0.004 & 0.000 & {$[0.004,0.018]$} & 0.040 & 0.034 & 0.000 & {$[-0.027,0.107]$} \\
C & -6.794 & 0.488 & 0.005 & {$[-7.750,-5.844]$} & -5.486 & 4.644 & 0.046 & {$[-14.461,3.665]$} \\
\hline
\end{tabular}

Table 8 reports the impact of TSEI*Education joint variable on both air quality and overall environmental performance. Education level can be used as a proxy to indicate the public's ability to adapt to a new technology or a new lifestyle, which also makes sense for the sharing economy activities (e.g., providing accessible communication between organizations and their users) [74]. Therefore, a joint variable of TSEI*Education was used to examine whether or not education together with sharing economy level contributes to a greener environment. The findings suggest that the interaction variable of TSEI Education has a posterior mean of -0.002 and a $95 \%$ credible interval estimation range of $[-0.003,-0.001]$ for $L n \mathrm{CO}_{2} p c$. This result implies that a high education level together with a high sharing economy index lowers carbon emissions. Countries with high sharing economy index scores and a high education level tend to decrease carbon emissions and increase environmental performance, mainly because education raises awareness about the environment. 
Table 8. Joint effect of TSEI and education on carbon emissions and overall environmental performance.

\begin{tabular}{ccccccccc}
\hline & \multicolumn{3}{c}{ LnCO ${ }_{2} p c$} & & \multicolumn{1}{c}{ EPI } \\
\cline { 2 - 8 } & Mean & S.D. & MCSE & 95\% Cred Interval & Mean & S.D. & MCSE & 95\% Cred Interval \\
\hline TSEI & 0.110 & 0.039 & 0.000 & {$[0.033,0.187]$} & 0.016 & 0.388 & 0.004 & {$[-0.755,0.761]$} \\
TSEI $\times$ Education & -0.011 & 0.003 & 0.000 & {$[-0.018,-0.004]$} & 0.008 & 0.033 & 0.000 & {$[-0.056,0.075]$} \\
LnGDPpc & 0.639 & 0.077 & 0.001 & {$[0.488,0.789]$} & 5.391 & 0.744 & 0.007 & {$[3.910,6.866]$} \\
Industrial & 0.022 & 0.004 & 0.000 & {$[0.013,0.031]$} & -0.167 & 0.043 & 0.000 & {$[-0.255,-0.083]$} \\
Popdensity & -0.043 & 0.074 & 0.001 & {$[-0.188,0.104]$} & -1.763 & 0.713 & 0.007 & {$[-3.181,-0.376]$} \\
Education & 0.150 & 0.028 & 0.000 & {$[0.096,0.206]$} & 0.547 & 0.271 & 0.003 & {$[0.014,1.077]$} \\
Tradefreedom & -0.002 & 0.006 & 0.000 & {$[-0.013,0.010]$} & 0.153 & 0.055 & 0.001 & {$[0.045,0.261]$} \\
Urban & 0.008 & 0.003 & 0.000 & {$[0.001,0.014]$} & 0.056 & 0.033 & 0.000 & {$[-0.008,0.120]$} \\
C & -6.889 & 0.482 & 0.005 & {$[-7.848,-5.933]$} & -5.359 & 4.707 & 0.047 & {$[-14.517,3.936]$} \\
\hline
\end{tabular}

In spite of the fact that large manufacturing countries usually have more $\mathrm{CO}_{2}$ emissions (see the $\mathrm{CO}_{2}$ emissions data of World Bank database), the current study is particularly interested in whether or not a high sharing economy level can decrease the negative impact of manufacturing on the environment. Therefore, this paper used a joint variable of TSEI*Urban*Industrial to examine the interactive impact of the sharing economy level together with urbanization and manufacturing level. The results given in Table 9 indicate that the joint variable of TSEI*Urban*Industrial is negatively associated with $\mathrm{CO}_{2}$ emissions. It is clear that the industrial variable has a negative impact on the environment. Surprisingly, the findings show that the manufacturing countries with a high sharing economy index together with high urbanization have comparatively low carbon emissions. The result of EPI shows that TSEI*Urban*Industrial has a positive mean. This result documents that major manufacturing countries (i.e., China, the USA, Japan, Germany, Korea, India, Italy, France, the UK, and Brazil) contribute positively to the overall environmental performance, due to their environmentally friendly high value-added production and high-tech policy implications. Another possible explanation is that people are motivated by environmental benefits offered by sharing economy activities, claiming reduced environmental hazards [75]. Contrary to expectations, the major manufacturing countries $t$ with high sharing economy practices and high urbanization have comparatively low carbon emissions and high environmental performance. This finding underlines the importance of sharing economy practices in large manufacturing-oriented countries, where people can also easily access sharing economy platforms.

Table 9. Joint effect of TSEI, urbanization, and industrialization on carbon emissions and overall environmental performance.

\begin{tabular}{|c|c|c|c|c|c|c|c|c|}
\hline & \multicolumn{4}{|c|}{$\mathrm{LnCO}_{2} p c$} & \multicolumn{4}{|c|}{ EPI } \\
\hline & Mean & S.D. & MCSE & 95\% Cred Interval & Mean & S.D. & MCSE & 95\% Cred Interval \\
\hline TSEI & 0.024 & 0.015 & 0.000 & {$[-0.005,0.052]$} & 0.060 & 0.139 & 0.001 & {$[-0.217,0.337]$} \\
\hline $\begin{array}{l}\text { TSEI } \times \text { Urban } \\
{ }^{*} \text { Industrial }\end{array}$ & $-3 \times 10^{-5}$ & 0.000 & 0.000 & {$\left[-5 \times 10^{-5},-1 \times 10^{-5}\right]$} & $-3 \times 10^{-5}$ & 0.000 & 0.000 & {$\left[-1 \times 10^{-4}, 2 \times 10^{-4}\right]$} \\
\hline LnGDPpc & 0.675 & 0.077 & 0.001 & {$[0.526,0.828]$} & 5.357 & 0.736 & 0.007 & {$[3.909,6.824]$} \\
\hline Industrial & 0.022 & 0.005 & 0.000 & {$[0.013,0.031]$} & -0.168 & 0.043 & 0.000 & {$[-0.253,-0.083]$} \\
\hline Popdensity & -0.050 & 0.075 & 0.001 & {$[-0.196,0.099]$} & -1.736 & 0.715 & 0.007 & {$[-3.131,-0.335]$} \\
\hline Education & 0.127 & 0.027 & 0.000 & {$[0.074,0.181]$} & 0.565 & 0.265 & 0.003 & {$[0.037,1.080]$} \\
\hline Tradefreedom & -0.001 & 0.006 & 0.000 & {$[-0.012,0.010]$} & 0.151 & 0.056 & 0.001 & {$[0.041,0.259]$} \\
\hline Urban & 0.009 & 0.003 & 0.000 & {$[0.002,0.015]$} & 0.055 & 0.033 & 0.000 & {$[-0.008,0.120]$} \\
\hline $\mathrm{C}$ & -7.105 & 0.502 & 0.005 & {$[-8.094,-6.117]$} & -5.010 & 4.802 & 0.049 & {$[-14.587,4.378]$} \\
\hline
\end{tabular}

Similarly, this paper used a joint variable of TSEI*Education*Industrial to examine the relationship between the sharing economy level, education level, and manufacturing on carbon emissions and environmental performance (see Table 10). The result of the joint variable has a mean of $-1 \times 10^{-5}$ negative impact on $\mathrm{CO}_{2}$ emissions. Given that both the Education and Industrial variables have positive relationship with $L n \mathrm{CO}_{2} p c$, it is clear that a 
high level of sharing economy and education in manufacturing countries can be helpful to limit carbon emissions.

Table 10. Joint effect of TSEI, education, and industrialization on carbon emissions and overall environmental performance.

\begin{tabular}{|c|c|c|c|c|c|c|c|c|}
\hline & \multicolumn{4}{|c|}{$\mathrm{LnCO}_{2} p c$} & \multicolumn{4}{|c|}{$E P I$} \\
\hline & Mean & S.D. & MCSE & $95 \%$ Cred Interval & Mean & S.D. & MCSE & $95 \%$ Cred Interval \\
\hline TSEI & -0.006 & 0.013 & 0.000 & {$[-0.018,0.031]$} & 0.110 & 0.120 & 0.001 & {$[-0.123,0.351]$} \\
\hline $\begin{array}{l}\text { TSEI } \times \text { Education } \\
\text { *Industrial }\end{array}$ & $-1 \times 10^{-5}$ & 0.000 & 0.000 & {$\left[-2 \times 10^{-4},-8 \times 10^{-6}\right]$} & $-1 \times 10^{-5}$ & 0.000 & 0.000 & {$\left[-9 \times 10^{-4}, 9 \times 10^{-4}\right]$} \\
\hline LnGDPpc & 0.666 & 0.078 & 0.001 & {$[0.513,0.818]$} & 5.382 & 0.734 & 0.007 & {$[3.942,6.847]$} \\
\hline Industrial & 0.022 & 0.005 & 0.000 & {$[0.012,0.031]$} & -0.165 & 0.045 & 0.000 & {$[-0.255,-0.077]$} \\
\hline Popdensity & -0.048 & 0.076 & 0.001 & {$[-0.199,0.098]$} & -1.762 & 0.719 & 0.007 & {$[-3.161,-0.324]$} \\
\hline Education & 0.135 & 0.028 & 0.000 & {$[0.078,0.188]$} & 0.564 & 0.264 & 0.003 & {$[0.047,1.079]$} \\
\hline Tradefreedom & -0.002 & 0.006 & 0.000 & {$[-0.013,0.010]$} & 0.152 & 0.056 & 0.001 & {$[0.043,0.261]$} \\
\hline Urban & 0.007 & 0.003 & 0.000 & {$[0.000,0.014]$} & 0.056 & 0.033 & 0.000 & {$[-0.009,0.121]$} \\
\hline $\mathrm{C}$ & -6.948 & 0.497 & 0.005 & {$[-7.928,-5.966]$} & -5.427 & 4.759 & 0.048 & {$[-14.935,3.935]$} \\
\hline
\end{tabular}

\subsection{Robustness Check}

Table 11 reports the robustness results. The countries with 0 TSEI were excluded from the sample and the analyses were re-run. The findings show the posterior mean of TSEI is negative $(-0.015)$, with a $95 \%$ credible interval ranging from -0.026 to -0.003 . TSEI has a positive posterior mean (0.121), with a 95\% credible interval range from 0.012 to 0.229 . Overall, the results are similar to those reported in Table 5, even if the countries with 0 TSEI were excluded. The efficiency checks of the MCMC simulation also gave similar results. The graphs are illustrated in the Appendix A (Figures A1 and A2).

Table 11. Robustness check of excluding the zero TSEI sample.

\begin{tabular}{ccccccccc}
\hline & \multicolumn{3}{c}{ LnCO $_{2} p c$} & & \multicolumn{2}{c}{ EPI } \\
\cline { 2 - 9 } & Mean & S.D. & MCSE & 95\% Cred Interval & Mean & S.D. & MCSE & 95\% Cred Interval \\
\hline TSEI & -0.014 & 0.006 & 0.000 & {$[-0.026,-0.002]$} & 0.114 & 0.061 & 0.001 & {$[0.005,0.232]$} \\
LnGDPpc & 0.620 & 0.083 & 0.001 & {$[0.454,0.782]$} & 4.787 & 0.817 & 0.008 & {$[3.172,6.373]$} \\
Industrial & 0.023 & 0.005 & 0.000 & {$[0.013,0.032]$} & -0.166 & 0.046 & 0.000 & {$[-0.257,-0.074]$} \\
Popdensity & -0.030 & 0.073 & 0.001 & {$[-0.173,0.113]$} & -1.436 & 0.724 & 0.007 & {$[-2.866,-0.035]$} \\
Education & 0.127 & 0.029 & 0.000 & {$[0.069,0.186]$} & 0.726 & 0.283 & 0.003 & {$[0.169,1.273]$} \\
Tradefreedom & -0.004 & 0.006 & 0.000 & {$[-0.016,0.007]$} & 0.187 & 0.058 & 0.001 & {$[0.072,0.301]$} \\
Urban & 0.008 & 0.003 & 0.000 & {$[0.001,0.015]$} & 0.051 & 0.034 & 0.000 & {$[-0.016,0.119]$} \\
C & -6.321 & 0.534 & 0.005 & {$[-7.373,-5.282]$} & -4.072 & 5.246 & 0.052 & {$[-14.265,6.221]$} \\
\hline
\end{tabular}

Note: The sample size was reduced to 147 after excluding countries with 0 TSEI.

To test whether the potential endogeneity problem (the sharing economy variable might be correlated with causally important omitted variables in the error term) makes the regression biased, this paper used the Broadband variable as an instrument, with 2SLS (two stage least square) (because Markov Chain Monte Carlo is used to explore the posterior distribution, the instrument variable cannot be involved in the Bayesian regression) as a robustness check. Regressions (1) and (2) of Table 12 report the results for $L_{N C O} p c$ in the first- and second-stage regressions. Regressions (3) and (4) provide the results for the $E P I$. The results in the second stage are similar to the results of the Bayesian regressions, in which TSEI has negative relationship with $\mathrm{CO}_{2}$ emissions and a positive impact on the overall environmental performance. The regressions with the instrument support the robustness of the Bayesian regressions. 
Table 12. Robustness check with 2SLS.

\begin{tabular}{|c|c|c|c|c|}
\hline & (1) & (2) & (3) & (4) \\
\hline & 2SLS-First & 2SLS-Second & 2SLS-First & 2SLS-Second \\
\hline & TSEI & $\mathrm{LnCO}_{2} p c$ & TSEI & $E P I$ \\
\hline TSEI & & $\begin{array}{c}-0.053^{* *} \\
(0.025)\end{array}$ & & $\begin{array}{c}0.320 \\
(0.223)\end{array}$ \\
\hline Broadband & $\begin{array}{c}30.544^{* * *} \\
(8.761)\end{array}$ & & $\begin{array}{c}30.544^{* * *} \\
(8.761)\end{array}$ & \\
\hline Constant & $\begin{array}{l}-8.447 \\
(7.314)\end{array}$ & $\begin{array}{c}-7.652^{* * *} \\
(0.790)\end{array}$ & $\begin{array}{l}-8.447 \\
(7.314)\end{array}$ & $\begin{array}{l}-0.370 \\
(7.006)\end{array}$ \\
\hline Control variables & YES & YES & YES & YES \\
\hline Observations & 165 & 165 & 165 & 165 \\
\hline R-squared & 0.423 & 0.809 & 0.423 & 0.790 \\
\hline F-statistic & 16.470 & & 16.470 & \\
\hline
\end{tabular}

\section{Conclusions}

Using cross-country data from 165 countries and Bayesian analysis, this paper addresses the impact of the sharing economy level on $\mathrm{CO}_{2}$ emissions and overall environmental performance. The findings reveal that while a high sharing economy level is negatively associated with $\mathrm{CO}_{2}$ emissions, it is positively associated with overall environmental performance. Using cross-sectional analysis, the results lead us to conclude that sharing activities help to improve the environment more than the negative effect from additional consumption stimulated by the sharing economy practices $[9,10,30,41]$. Our analysis further suggests that, while secondary industries and population density have a negative impact on environmental performance, high income, education, and trade freedom improve the quality of the environment. These results support the view that countries with a high population and a high portion of secondary industries threaten the environment. In addition, the results show that trade freedom improves both air quality and overall environmental performance.

The results of the joint effect of sharing economy level with countries' characteristics have interesting results for policy implications. As expected, the joint effect of both urbanization and the education level with the sharing economy index is negative on carbon emissions and positive on overall environmental performance. Sharing economy platforms are more popular when there are high levels of urbanization and education $[36,37,66]$. Moreover, Internet access enhances the impact of the sharing economy index on environment quality, which is consistent with the common expectation that online sharing activities highly depend on Internet broadband access [65]. One of the striking findings of this paper is that a high sharing economy index together with high urbanization or high education level in manufacturing countries tends to lead to comparatively low carbon emissions and high overall environmental performance. This finding can be attributed to the production policies of the main manufacturing countries. In particular, many of these countries are developed nations and are likely to invest in more technology. The other countries are emerging economies, which are moving from labor-intensive to capital-intensive manufacturing.

An immediate implication of this paper is that we can recommend that policy makers and practitioners should move beyond traditional ownership and consumption patterns to understand the impact of the sharing economy level on the environment. The findings suggest that environmental degradation can decrease when the high sharing economy level becomes an integral part of society thanks to broadband access and education level.

For future studies, it would be interesting to investigate in greater depth in which industries and how the sharing economy practices could reduce environmental degradation. In this context, policy makers should provide guidelines to regulate sharing economy 
business models, together with changing ownership and consumption patterns, to improve the quality of the environment.

\section{Limitations}

Sample size was the limitation of the current study. Unfortunately, TSEI data are only available for the year 2018 and this leads us to deal with cross-sectional data and use regression analyses. The data from Timbro have not yet been updated. Hence, we cannot carry out further analyses using time series or panel data. However, based on the available current cross-sectional data, this paper tries its best to fill the gap in the existing literature given that only a very few studies have attempted to estimate the impact of the sharing economy practices on the environment at a national level. It also gives an example for further studies.

Author Contributions: Conceptualization, W.Y.; data curation, Z.C.; formal analysis, W.Y. and Z.C.; methodology, B.K.-U. and Z.C.; writing-original draft, B.K.-U.; writing-review and editing, W.Y. and B.K.-U. All authors have read and agreed to the published version of the manuscript.

Funding: This work funded by the social science fund of Jiangsu Province China (17EYC004) and the Zhishan Youth Scholar Program of SEU (2242019R40039).

Institutional Review Board Statement: Not applicable.

Data Availability Statement: Data that we used in the paper are attached.

Acknowledgments: We are grateful to the anonymous referees for helpful comments and suggestions for improvements. All remaining errors are ours.

Conflicts of Interest: The authors declare no conflict of interest.

\section{Appendix A}

\section{LNCO2pc:TSEI}

Trace

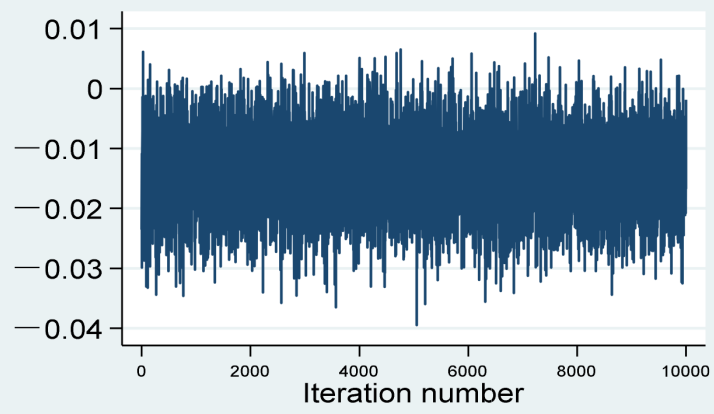

Autocorrelation

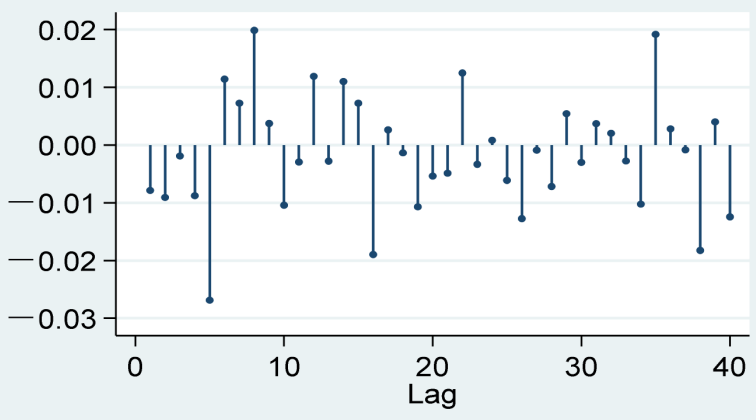

Histogram

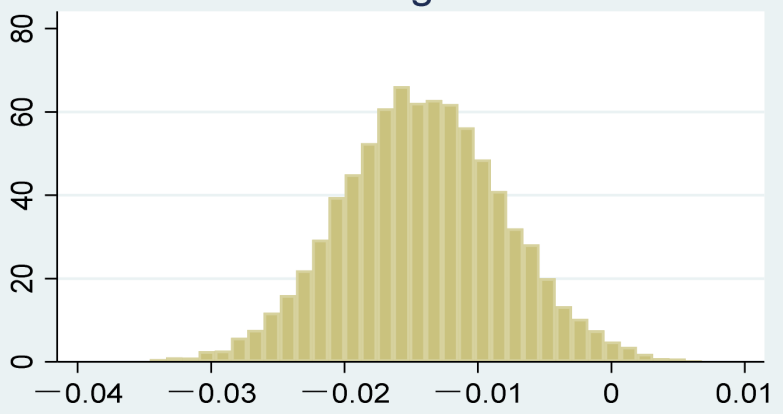

Density

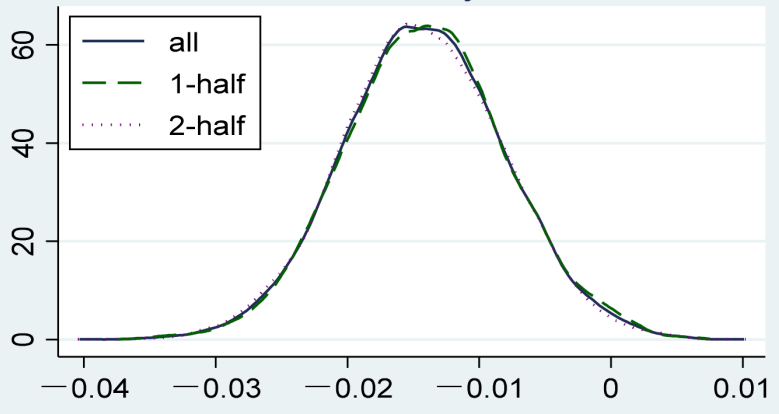

Figure A1. Efficiency check for the MCMC simulation of TSEI to $\mathrm{LnCO}_{2} p c$ when excluding the TSEI zero sample. 


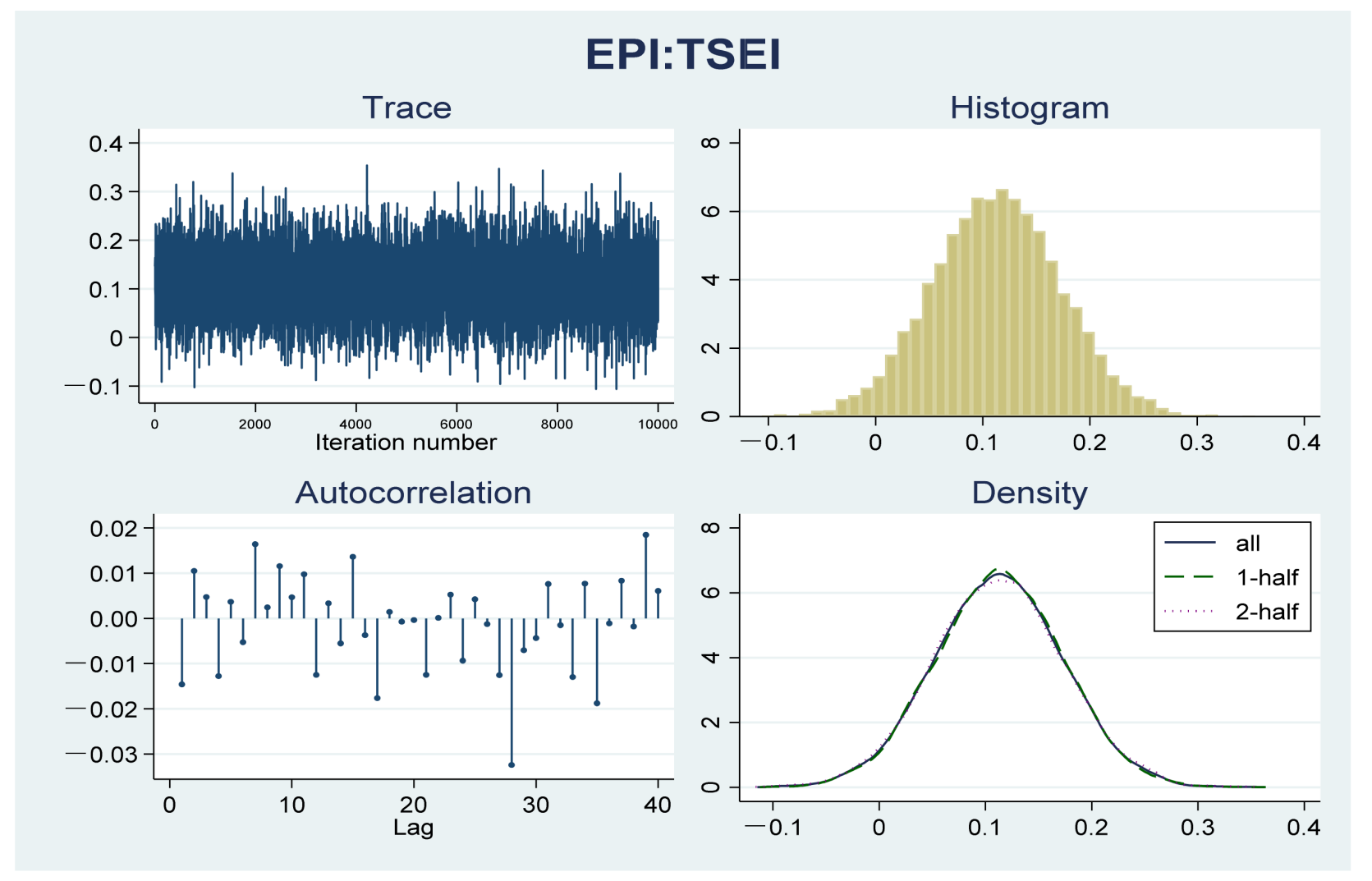

Figure A2. Efficiency check for the MCMC simulation of TSEI to EPI when excluding the TSEI zero sample.

\section{References}

1. Hamari, J.; Sjklint, M.; Ukkonen, A. The sharing economy: Why people participate in collaborative consumption. J. Assoc. Inf. Sci. Technol. 2016, 67, 2047-2059. [CrossRef]

2. Chandler, A. What Should the Sharing Economy Really Be Called? The Atlantic: Boston, MA, USA, 2016.

3. Martin, C.J. The sharing economy: A pathway to sustainability or a nightmarish form of neoliberal capitalism? Ecol. Econ. 2016, 121, 149-159. [CrossRef]

4. Acquier, A.; Daudigeos, T.; Pinkse, J. Promises and paradoxes of the sharing economy: An organizing framework. Technol. Forecast. Soc. 2017, 125, 1-10. [CrossRef]

5. Cherry, C.E.; Pidgeon, N.F. Is sharing the solution? Exploring public acceptability of the sharing economy. J. Clean. Prod. 2018, 195, 939-948. [CrossRef]

6. Nijland, H.; Meerkerk, J.V. Mobility and environmental impacts of car sharing in the Netherlands. Environ. Innov. Soc. Transit. 2017, 23, 84-91. [CrossRef]

7. Shaheen, S.; Cohen, A.; Jaffee, M. Innovative Mobility: Carsharing Outlook Carsharing Market Overview, Analysis, and Trends; UC Berkeley: Berkeley, CA, USA; Transportation Sustainability Research Center: Richmond, CA, USA, 2020.

8. Zhu, M.; Hu, X.; Lin, Z.; Li, J.; Wang, C. Intention to adopt bicycle-sharing in China: Introducing environmental concern into the theory of planned behavior model. Environ. Sci. Pollut. R 2020, 27, 41740-41750. [CrossRef]

9. Cao, Y.; Shen, D. Contribution of shared bikes to carbon dioxide emission reduction and the economy in Beijing. Sustain. Cities Soc. 2019, 51, 101749. [CrossRef]

10. Chen, T.D.; Kockelman, K.M. Management of a shared autonomous electric vehicle fleet: Implications of pricing schemes. Transp. Res. Rec. J. Transp. Res. Board 2016, 2572, 37-46. [CrossRef]

11. Doka, G.; Ziegler, S. Complete life cycle assessment for vehicle models of the mobility carsharing fleet Switzerland. In Proceedings of the Presented at the 1t Swiss Transport Research Conference, Ascona, Switzerland, 1-3 March 2001. Available online: www.strc.ch/conferences/2001/doka.pdf (accessed on 9 October 2020).

12. Millard-Ball, A.; Murray, G.; Schure, J.T.; Fox, C.; Burkhardt, J. Car-Sharing: Where and How It Succeeds; TCRP Report Transportation Research Board of the National Academies: Washington, DC, USA, 2005.

13. Liu, X.; Chen, H. Sharing economy: Promote its potential to sustainability by regulation. Sustainability 2020, 12, 919. [CrossRef]

14. Muray, I. Driving Innovation: Timbro Index Charts Scope of Global Sharing Economy; Competitive Enterprise Institute: Washington, DC, USA, 2018. Available online: cei.org/blog/driving-innovation-timbro-index-charts-scope-of-global-sharing-economy/ (accessed on 2 November 2020). 
15. Auffhammer, M.; Carson, R.T. Forecasting the path of China's $\mathrm{CO}_{2}$ emissions using province-level information. J. Environ. Econ. Manag. 2008, 55, 229-247. [CrossRef]

16. Hanif, I.; Gago-de-Santos, P. The importance of population control and macroeconomic stability to reducing environmental degradation: An empirical test of the environmental Kuznets curve for developing countries. Environ. Dev. 2017, 23, 1-9. [CrossRef]

17. Akbar, Y.H.; Tracogna, A. The sharing economy and the future of the hotel industry: Transaction cost theory and platform economics. Int. J. Hosp. Manag. 2018, 71, 91-101. [CrossRef]

18. Ferrell, O.C.; Ferrell, L.; Huggins, K. Seismic shifts in the sharing economy: Shaking up marketing channels and supply chains. J. Mark. Channels 2017, 24, 3-12. [CrossRef]

19. Tian, L.; Jiang, B. Effects of consumer-to-consumer product sharing on distribution channel. Prod. Oper. Manag. 2018, 27, 350-367. [CrossRef]

20. Chase, R. Peers Inc.: How People and Platforms Are Inventing the Collaborative Economy and Reinventing Capitalism; Public Affairs: New York, NY, USA, 2015.

21. Davlembayeva, D.; Papagiannidis, S.; Alamanos, E. Sharing economy: Studying the social and psychological factors and the outcomes of social exchange. Technol. Forecast. Soc. 2020, 158, 120143. [CrossRef]

22. Ciulli, F.; Kolk, A. Incumbents and business model innovation for the sharing economy: Implications for sustainability. J. Clean. Prod. 2019, 214, 995-1010. [CrossRef]

23. Demailly, D.; Novel, A.S. The Sharing Economy: Make It Sustainable; IDDRI: Paris, France, 2014.

24. Schor, J.B. Does the sharing economy increase inequality within the eighty percent? Findings from a qualitative study of platform providers. Camb. J. Reg. Soc. Ecno. 2017, 10, 263-279. [CrossRef]

25. Frenken, K. Political economies and environmental futures for the sharing economy. Philos. Trans. R. Soc. A Math. Phys. Eng. Sci. 2017, 375, 20160367. [CrossRef]

26. Ritter, M.; Schanz, H. The sharing economy: A comprehensive business model framework. J. Clean. Prod. 2019, 213, 320-331. [CrossRef]

27. Jabbour, C.J.C.; Fiorini, P.D.C.; Wong, C.W.Y.; Jugend, D.; Jabbour, A.B.L.D.S.; Seles, B.M.R.P.; Pinheiro, M.A.P.; da Silva, H.M.R. First-mover firms in the transition towards the sharing economy in metallic natural resource-intensive industries: Implications for the circular economy and emerging industry 4.0 technologies. Resour. Policy 2020, 66, 101596. [CrossRef]

28. Lim, W.M. Sharing economy: A marketing perspective. Australas. Mark. J. 2020, 28, 4-13. [CrossRef]

29. Hou, L. Destructive sharing economy: A passage from status to contract. Comput. Law Secur. Rev. 2018, 34, 965-976. [CrossRef]

30. Morseletto, P. Targets for a circular economy. Resour. Conserv. Recycl. 2020, 153, 104553. [CrossRef]

31. Sumter, D.; De Koning, J.; Bakker, C.; Balkenende, R. Circular economy competencies for design. Sustainability 2020, 12, 1561. [CrossRef]

32. Lakatos, E.S.; Yong, G.; Szilagyi, A.; Clinci, D.S.; Georgescu, L.; Iticescu, C.; Cioca, L.-I. Conceptualizing core aspects on circular economy in cities. Sustainability 2021, 13, 7549. [CrossRef]

33. Kristoffersen, E.; Blomsma, F.; Mikalef, P.; Li, J.Y. The smart circular economy: A digital-enabled circular strategies framework for manufacturing companies. J. Bus. Res. 2020, 120, 241-261. [CrossRef]

34. Dagilienè, L.; Varaniūtè, V.; Bruneckienè, J. Local governments' perspective on implementing the circular economy: A framework for future solutions. J. Clean. Prod. 2021, 310, 127340. [CrossRef]

35. Hjaltadóttir, R.E.; Hild, P. Circular economy in the building industry European policy and local practices. Eur. Plan. Stud. 2021, 29, 2226-2251. [CrossRef]

36. Andreotti, A.; Anselmi, G.; Eichhorn, T.; Hoffmann, C.P.; Micheli, M. Participation in the Sharing Economy. 2017. Available online: ssrn.com/abstract=2961745 (accessed on 2 May 2020).

37. Eichhorn, T.; Jürss, S.; Hoffmann, C.P. Dimensions of digital inequality in the sharing economy. Inf. Commun. Soc. 2020, 1-18. [CrossRef]

38. Bucher, E.; Fieseler, C.; Lutz, C. What's mine is yours (for a nominal fee)—Exploring the spectrum of utilitarian to altruistic motives for Internet-mediated sharing. Comput. Hum. Behav. 2016, 62, 316-326. [CrossRef]

39. Ala-Mantila, S.; Ottelin, J.; Heinonen, J.; Junnila, S. To each their own? The greenhouse gas impacts of intra-household sharing in different urban zones. J. Clean. Prod. 2016, 135, 356-367. [CrossRef]

40. Paundra, J.; Rook, L.; Dalen, J.V.; Ketter, W. Preferences for car sharing services: Effects of instrumental attributes and psychological ownership. J. Environ. Psychol. 2017, 53, 121-130. [CrossRef]

41. Belk, R.; Eckhardt, G.; Bardhi, F. Handbook of the Sharing Economy; Edward Elgar Publishing: Cheltenham, UK, 2019.

42. Li, Y.; Ding, R.G.; Cui, L.; Lei, Z.M.; Mou, J. The impact of sharing economy practices on sustainability performance in the Chinese construction industry. Resour. Conserv. Recycl. 2019, 150, 104409. [CrossRef]

43. Li, Y.; Lim, M.K.; Tan, Y.S.; Lee, S.Y.; Tseng, M.L. Sharing economy to improve routing for urban logistics distribution using electric vehicles. Resour. Conserv. Recycl. 2020, 153, 104585. [CrossRef]

44. Rydén, C.; Morin, E. MOSES Mobility Services for Urban Sustainability, Environmental Assessment. Report WP6. 2005. Available online: communauto.com/images/Moses_environnement.pdf (accessed on 16 June 2020).

45. Botsman, R.; Rogers, R. Beyond Zipcar: Collaborative Consumption; Harvard Business Review: Brighton, MA, USA, $2010 ;$ p. 88.

46. Barnes, S.J.; Mattsson, J. Understanding current and future issues in collaborative consumption: A four-stage Delphi study. Technol. Forecast. Soc. Chang. 2016, 104, 200-211. [CrossRef] 
47. Frenken, K.; Schor, J. Putting the sharing economy into perspective. Environ. Innov. Soc. Transit. 2017, 23, 3-10. [CrossRef]

48. Lai, M.K.W.; Ho, A.P.Y. Unravelling potentials and limitations of sharing economy in reducing unnecessary consumption: A social science perspective. Resour. Conserv. Recycl. 2020, 153, 104546. [CrossRef]

49. Hu, J.Y.; Liu, Y.L.; Yuen, T.W.W.; Lim, M.K.; Hu, J.L. Do green practices really attract customers? The sharing economy from the sustainable supply chain management perspective. Resour. Conserv. Recycl. 2019, 149, 177-187. [CrossRef]

50. Tussyadiah, I.P.; Pesonen, J. Impacts of peer-to-peer accommodation use on travel patterns. J. Travel Res. 2016, 55, 1022-1040. [CrossRef]

51. Czepkiewcisz, M.; Heinonen, J.; Ottelin, J. Why do urbanites travel more than do others? A 138 review of associations between urban form and long-distance leisure travel. Environ. Res. Lett. 2018, 13, 073001. [CrossRef]

52. Fishman, E.; Washington, S.; Haworth, N. Bike share's impact on car use: Evidence from the United States, Great Britain, and Australia. Transp. Res. Part D Transp. Environ. 2014, 31, 13-20. [CrossRef]

53. Stemler, A. Betwixt and between: Regulating the shared economy. Urban Law J. 2016, 43, 32-70. [CrossRef]

54. Ganapati, S.; Reddick, C.G. Prospects and challenges of sharing economy for the public sector. Gov. Inf. Q 2018, 35, 77-87. [CrossRef]

55. Baumber, A.; Scerri, M.; Schweinsberg, S. Technological forecasting and social change. Technol. Forecas. Soc. Chang. 2019, 146, 12-23. [CrossRef]

56. Mi, Z.; Coffman, D. The sharing economy promotes sustainable societies. Nat. Commun. 2019, 10, 1214. [CrossRef]

57. Dunson, D.B. Commentary: Practical advantages of Bayesian analysis of epidemiologic data. Am. J. Epidemiol. 2001, 153, 1222-1226. [CrossRef]

58. Schoot, R.; Broere, J.J.; Perryck, K.H.; Zondervan-Zwijnenburg, M.; Loey, N. Analyzing small data sets using Bayesian estimation: The case of posttraumatic stress symptoms following mechanical ventilation in burn survivors. Eur. J. Psychotraumatol. 2015, 6, 25216. [CrossRef]

59. Rubin, G. Inference from iterative simulation using multiple sequences. Stat. Sci. 1992, 7, 457-472.

60. Jiang, H.; Liu, C.Y. Economic policy uncertainty, CEO characteristics and firm R\&D expenditure: A Bayesian analysis. Appl. Econ. 2020, 52, 3709-3731.

61. Wang, Q.; Wu, S.D.; Zeng, Y.E.; Wu, B.W. Exploring the relationship between urbanization, energy consumption, and $\mathrm{CO}_{2}$ emissions in different provinces of China. Renew. Sustain. Energy Rev. 2016, 54, 1563-1579. [CrossRef]

62. Chen, H.; Hao, Y.; Li, J.; Song, X. The impact of environmental regulation, shadow economy, and corruption on environmental quality: Theory and empirical evidence from China. J. Clean. Prod. 2018, 195, 200-214. [CrossRef]

63. Mikayilov, J.I.; Hasanov, F.J.; Galeotti, M. Decoupling of $\mathrm{CO}_{2}$ emissions and GDP: A time-varying cointegration approach. Ecol. Indic. 2018, 95, 615-628. [CrossRef]

64. Managi, S.; Jena, P.R. Environmental productivity and Kuznets curve in India. Ecol. Econ. 2008, 65, 432-440. [CrossRef]

65. Balaguer, J.; Cantavella, M. The role of education in the Environmental Kuznets Curve, Evidence from Australian data. Ecol. Econ. 2018, 70, 289-296. [CrossRef]

66. Grossman, G.M.; Krueger, A.B. Environmental impacts of a North American free trade agreement. Papers 1991. [CrossRef]

67. Neill, D.O.; Fanning, A.L.; Lamb, W.F.; Steinberger, J.K. A good life for all within planetary boundaries. Nat. Sustain. 2018, 1, 88-95.

68. Madlener, R.; Sunak, Y. Impacts of urbanization on urban structures and energy demand: What can we learn for urban energy planning and urbanization management? Sustain. Cities Soc. 2011, 1, 45-53. [CrossRef]

69. Ohlan, R. The impact of population density, energy consumption, economic growth and trade openness on $\mathrm{CO}_{2}$ emissions in India. Nat. Hazards 2015, 79, 1409-1428. [CrossRef]

70. Zhang, N.; Yu, K.; Chen, Z. How does urbanization affect carbon dioxide emissions? A cross-country panel data analysis. Energy Policy 2017, 107, 678-687. [CrossRef]

71. Wang, Y.; Kang, Y.; Wang, J.; Xu, L. Panel estimation for the impacts of population-related factors on $\mathrm{CO}_{2}$ emissions: A regional analysis in China. Ecol. Indic. 2017, 78, 322-330. [CrossRef]

72. Bergh, A.; Funcke, A. Does Country Level Social Trust Predict the Size of the Sharing Economy? IFN Working Paper. 2016. Available online: https:/ /www.ifn.se/wfiles/wp/wp1130.pdf (accessed on 23 April 2020).

73. Curtis, S.K. Business model patterns in the sharing economy. Sustain. Prod. Consum. 2021, 27, 1650-1671. [CrossRef]

74. Mont, O.; Curtis, S.K.; Palgan, Y.V. Organisational response strategies to COVID-19 in the sharing economy. Sustain. Prod. Consum. 2021, 28, 52-70. [CrossRef]

75. Gupta, P.; Chauhan, S. Mapping intellectual structure and sustainability claims of sharing economy research-A literature review. Sustain. Prod. Consum. 2021, 25, 347-362. [CrossRef] 